\title{
Hybrydowa ciecz przemywająca do oczyszczania przestrzeni pierścieniowej otworu wiertniczego
}

\begin{abstract}
Zapewnienie szczelności w przestrzeni pierścieniowej pomiędzy kolumnami rur oraz poza nimi odgrywa główną rolę w wyeliminowaniu niekontrolowanych przepływów mediów złożowych. Aby osiągnąć taki efekt należy zapuszczoną kolumnę rur okładzinowych uszczelnić, poprzez wtłoczenie w przestrzeń pierścieniową lub pozarurową zaczynu cementowego. Podczas tłoczenia zaczynu cementowego z przestrzeni pierścieniowej usuwa się płuczkę wiertniczą. Nie zawsze jednak zaczyn cementowy ma możliwość efektywnego usunięcia pozostałości po płuczce. Żeby zabezpieczyć otwór przed ewentualnym przepływem gazu po zacementowaniu, niezbędne jest dokładne oczyszczenie przestrzeni pierścieniowej z osadu płuczkowego, poprzez przetłoczenie odpowiedniej cieczy przemywającej, a następnie całkowite wyparcie płuczki przez ciecz buforową i zaczyn cementowy. Zachowanie tych warunków oraz uzyskanie odpowiednio oczyszczonej przestrzeni pierścieniowej przed zabiegiem cementowania, pozwala uzyskać wymagane uszczelnienie i w pewnym stopniu zminimalizować możliwość zachodzenia niepożądanego zjawiska migracji gazu, na kontakcie płaszcza cementowego z powierzchniami na styku rury okładzinowej i formacji skalnej. Analizując problem poprawy oczyszczenia przestrzeni pierścieniowej, przeprowadzone zostały badania laboratoryjne nad opracowaniem nowego rodzaju hybrydowej cieczy przemywającej umożliwiającej zwiększenie efektywności usuwania osadu. Działanie cieczy hybrydowej polega zarówno na chemicznym, jak i mechanicznym usuwaniu pozostałości osadu płuczkowego. Podczas realizacji pracy badaniom poddano grupę środków oraz domieszek różnych frakcji stałych, których odpowiedni dobór ilościowy i jakościowy umożliwił zaprojektowanie hybrydowej cieczy przemywającej o bardzo dobrych parametrach oczyszczających. Przeprowadzone zostały badania efektywności usuwania osadu płuczkowego w symulatorze przepływu cieczy wiertniczych. Na podstawie uzyskanych wyników badań stwierdzono, że zarówno działanie środków powierzchniowo czynnych oraz dodatku drobnoziarnistych dodatków ściernych, a także ich odpowiednia koncentracja, przyczyniają się do poprawy efektywności usuwania pozostawionego na powierzchni skały osadu płuczkowego. Badania nad opracowaniem hybrydowej cieczy przemywającej i efektywności jej działania przeprowadzone zostały na podstawie pomiaru przyczepności stwardniałego zaczynu cementowego do formacji skalnej, z której usuwano wytworzony wcześniej osad płuczkowy. Na podstawie analizy uzyskanych wyników oraz ich korelacji z próbkami wzorcowymi, stwierdzono znaczną poprawę efektywności usuwania osadu płuczkowego.
\end{abstract}

Słowa kluczowe: ciecz przemywająca, hybrydowa ciecz przemywająca, przemywka, oczyszczenie przestrzeni pierścieniowej, środki powierzchniowo czynne, surfaktanty, środki ścierne, dodatki drobnoziarniste.

\section{Hybrid preflush fluid for cleaning of the annular space of the borehole}

Ensuring sealing-off in the annular space between casing string and beyond, plays an important role in eliminating uncontrolled flows of gaseous media. In order to achieve this effect, it is necessary to seal the casing column by the pumping of the cement slurry, into the annular space. During the pumping of the cement slurry from the annular space, the drilling mud is removed. However, it is not always possible to use cement slurry to effectively remove the remains of the mud. To eliminate the possibility of gas flow after cementing, it is necessary to thoroughly clean the annular space of the mud cake by pumping the preflush fluid, and then completely removing the mud by spacer fluid and cement slurry. Fulfilling these conditions and obtaining a properly cleaned annular space prior to cementation can help to improve the sealing and to some extent eliminate the possibility of undesirable gas migration at the point of contact of the cement sheath with the contact surfaces casing string and rock formation. Analyzing the problem of improving the cleaning of the annular space, laboratory tests have been carried out to develop a new type of hybrid preflush fluid that allows to increase the efficiency of filter cake removal. The hybrid fluid is relies on both chemical and mechanical removal of the residual mud cake. During the research, a group of agents and admixtures of various solid fractions were investigated, the appropriate quantitative and qualitative selection of which made it possible to design a hybrid washing fluid with very good purifying parameters. Tests on the efficiency of removing the filter cake in a drilling fluid flow simulator, was carried out. On the basis of the obtained test results, it was found that both 
surfactants and fine abrasive additives, as well as their appropriate concentration contributes to the improvement of removal efficiency of the mud cake on the surface of the rock. Research on the development of a hybrid washing fluid and effectiveness of its actions were conducted by determining the adhesion of the cement sheath to the rock formation, from which the previously produced filter cake was removed. Based on the analysis of the obtained results and their correlation to the standard samples, a significant improvement in the efficiency of removal of the mud cake was found.

Key words: preflush fluid, hybrid preflush fluid, wash fluid, cleaning of the annular space, surfactants, abrasives, fine-grain additives.

\section{Wprowadzenie}

Poprawne oczyszczenie przestrzeni pierścieniowej przed zabiegiem cementowania przyczynia się do uzyskania odpowiedniej szczelności na kontakcie: formacja skalna-płaszcz cementowy-rura okładzinowa, co wpływa na wyeliminowanie migracji bądź ekshalacji gazu po zacementowaniu. Efektywne oczyszczenie przestrzeni pierścieniowej i uszczelnienie kolumny rur zapewnia również wieloletnią eksploatację odwiertu, minimalizując oddziaływanie środowiska korozyjnego na kolumnę rur w warunkach agresywnych. Zagadnienie oczyszczania przestrzeni pierścieniowej obejmuje reologię cieczy wiertniczych, mechanikę płynów (przepływ cieczy w przestrzeni pierścieniowej), działanie środków chemicznych, środków powierzchniowo czynnych i surfaktantów oraz działania dodatków chemicznych $\mathrm{w}$ trakcie hydratacji i wiązania zaczynu cementowego $[1,5,8,10]$.

Zaobserwowano, że pomimo rozwoju techniki i technologii uszczelniania kolumn rur w wiertnictwie oraz znacznego postępu w tym kierunku, nadal odnotowywane są nieudane zabiegi cementowania. W związku z tym podjęte zostały prace badawcze nad poprawą oczyszczenia przestrzeni pierścieniowej $[6,11,15]$. Jak już wspomniano skuteczne uszczelnienie kolumn rur uzależnione jest od przeprowadzonego zgodnie z wymogami zabiegu cementowania. Jakość uszczelnienia przestrzeni pierścieniowej należy rozpatrywać pod kątem zastosowanych cieczy przemywających, cieczy buforowych, zaczynu cementowego oraz wpływu poszczególnych cieczy wyprzedzających na osad filtracyjny z płuczki wiertniczej oraz na formację skalną.

Analizując nieskuteczne uszczelnienia przestrzeni międzyrurowych i pozarurowych, nie można określić jednej głównej przyczyny występowania tego zjawiska. $\mathrm{W}$ obecnym stanie rozpoznania istnieje możliwość wytypowania różnych czynników, które mogą przyczyniać się do pojawiania się nieszczelności i dróg migracji gazu. Zaliczyć można tutaj czynniki geologiczne, techniczne, mechaniczne bądź organizacyjne $[3,4,6]$. $Z$ punktu widzenia poprawy oczyszczenia przestrzeni pierścieniowej, czyli przygotowania otworu przed zabiegiem cementowania kluczową grupę stanowią czynniki technologiczne. Do tej grupy, oprócz konstrukcji otworu, długości i średnicy kolumn rur okładzinowych, powierzchni poprzecznego prze- kroju przestrzeni pierścieniowej i stanu technicznego otworu, zalicza się przygotowanie otworu do rurowania i cementowania. Na tym właśnie etapie decydujące znaczenie ma między innymi rodzaj, skład i działanie stosowanej cieczy przemywającej [3, 4, 14].

Dodatkowo należy również wspomnieć o rodzaju i parametrach stosowanych podczas wiercenia płuczek wiertniczych (charakterystyka osadu płuczkowego) oraz o składzie i parametrach technologicznych użytego zaczynu cementowego $[12,14]$.

Po wytłoczeniu zaczynu cementowego poza kolumnę rur okładzinowych, na skutek kontaktu zaczynu z pozostałościami płuczki, zachodzą w zaczynie procesy, które mogą sprzyjać pojawieniu się gazu na kontakcie płaszcza cementowego z formacją skalną i rurą okładzinową. Dlatego też należy zapewnić dokładne oczyszczenie przestrzeni pierścieniowej bądź pozarurowej cementowanego interwału oraz odpowiednio usunąć płuczkę i pozostały po niej osad filtracyjny $[6,12,14]$. W przypadku niedostatecznego wyparcia płuczki wiertniczej i słabego usunięcia osadu płuczkowego, zachodzi możliwość powstawania kanalików dla migrującego gazu (rysunek 1) [3, 4]. Zjawisko takie może występować głównie na skutek niedokładnego wypłukania otworu przed zabiegiem cementowania lub w przypadku niecentrycznego ułożenia kolumn rur okładzinowych w otworze.

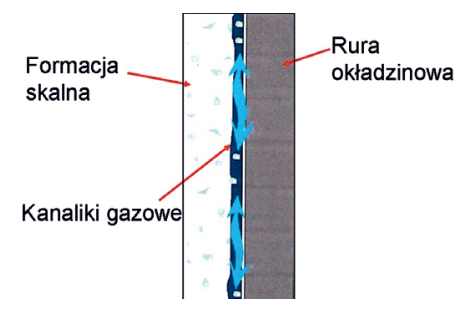

Rys. 1. Niski stopień wyparcia płuczki

Analizując przyczyny nieudanych zabiegów cementowania, które były przeprowadzone prawidłowo od strony technicznej, wywnioskowano, że stopień uszczelnienia rur zależy od rodzaju zastosowanej płuczki, a w szczególności jej właściwości inhibitacyjnych $[12,13]$ oraz odpowiedniego rodzaju i składu cieczy przemywającej, a także zaczynu cementowego. 
Wymienione ciecze odgrywają ważną rolę we wzajemnym oddziaływaniu podczas płukania i wypierania płuczki z otworu $\mathrm{w}$ trakcie cementowania, a przede wszystkim oddziaływaniu na odsłoniętą skałę, oraz poprzez utworzony na ścianie otworu osad filtracyjny, zawierający koloidalne cząstki fazy stałej i polimerów. Stwierdza się również, że jakość i ilość pozostawionego na ścianie otworu osadu płuczkowego wywiera znaczny wpływ na efektywność uszczelnienia kolumny rur, w związku z tym ważne jest jak najlepsze oczyszczenie przestrzeni pierścieniowej przed zabiegiem cementowania [7, 9, 13].

Dodatkowo należy wspomnieć, że istotnym zagadnieniem, mającym wpływ na jakość uszczelnienia przestrzeni pierścieniowej jest przyczepność stwardniałego zaczynu cementowego do skały poprzez resztki pozostałego osadu filtracyjnego. Jak wykazały badania, na szczelność połączenia układu skała-stwardniały zaczyn cementowy wpływa grubość i konsystencja osadu filtracyjnego [2, 12-14]. Grubość osadu zależy od stopnia jego wypłukania oraz czasu i intensywności płukania. Gruby, miękki osad może zostać zerodowany przez ciecz przemywającą o odpowiednich właściwościach i reżimie jej przepływu, natomiast cienki twardy osad w takich samych warunkach płukania może okazać się niezmywalny [13]. Dlatego też istotną rolę w takim przypadku może odgrywać ciecz hybrydowa, w której składzie oprócz środków powierzchniowo czynnych czy surfaktantów znajduje się dodatek drobnych frakcji materiałów ściernych. Ciecz taka charakteryzuje się dwufunkcyjnym charakterem działania, dzięki czemu wspomniana cienka warstwa twardego, skonsolidowanego osadu zostaje usunięta również wskutek mechanicznego zdzierania osadu. Należy pamiętać, że przy opracowywaniu wspomnianej cieczy hybrydowej istotny jest dobór dodatków i domieszek mających na celu ograniczenie frakcjonowania środków ściernych, a jednocześnie dobór środków, które podczas podnoszenia lepkości w hybrydowej cieczy przemywającej nie będą wywierały negatywnego działania (dodatkowej stabilizacji) dla pozostałości osadu płuczkowego. Dotychczas stosowano ciecze przemywające o głównie chemicznym działaniu na pozostałości osadu płuczkowego, natomiast w niniejszej publikacji omówiono efekt działania hybrydowej cieczy przemywającej.

\section{Przebieg prac badawczych}

Badania nad opracowaniem hybrydowej cieczy przemywającej były wykonywane w Laboratorium Zaczynów Uszczelniających INiG - PIB na podstawie norm: PN-85/G-02320 Cementy $i$ zaczyny cementowe do cementowania $w$ otworach wiertniczych; PN-EN 10426-2 Przemyst naftowy i gazowniczy. Cementy i materiaty do cementowania otworów. Część 2: Badania cementów wiertniczych oraz API SPEC 10 Specification for materials and testing for well cements.

Cykl badawczy, który został omówiony w dalszej części publikacji polegał na wykazaniu efektywności działania nowo opracowanej hybrydowej cieczy przemywającej. Działanie cieczy polegało na usunięciu wytworzonego na powierzchni próbki skalnej osadu płuczkowego. W celu przeprowadzenia prac badawczych skonstruowano w INiG - PIB urządzenie umożliwiające tłoczenie cieczy wiertniczych w obiegu zamkniętym (symulator przepływu cieczy wiertniczych - fotografia 1). Badania wykonano dla wytypowanych cieczy przemywających, które tłoczono przy stałej wartości wydatku tłoczenia oraz stałym czasie kontaktu cieczy przemywającej z próbką skały. Parametry tłoczenia dobrane zostały podczas badań wstępnych, w których przyjęto optymalną prędkość przepływu równą 11,2 1/min, co odpowiadało tłoczeniu cieczy w reżimie turbulentnym o wartości liczby Reynoldsa około 3150. Czas kontaktu cieczy przemywającej z powierzchnią próbki ustalono na 4 minuty, co na podstawie badań wstępnych stanowiło wartość skutkującą poprawną efektywnością usunięcia osadu. Zwiększenie czasu kontaktu mogłoby spowodować lepszą sku- teczność wymycia osadu, jednak przyjęto wartość czasu równą 4 minuty ze względu na to, że na tym etapie koncentrowano się na określeniu skuteczności działania cieczy hybrydowej, z pominięciem parametrów fizycznych i hydraulicznych.

Do prac badawczych zastosowano próbki piaskowca wycięte w kształcie walca o średnicy zewnętrznej $25 \mathrm{~mm}$ i długości $60 \mathrm{~mm}$ (fotografia 2). Rdzenie umieszczono w specjalnie skonstruowanym statywie (rysunek 2) umieszczonym wewnątrz rury z tworzywa (fotografia 3), w której odbywał się przepływ cieczy wiertniczych (płuczka, ciecz przemywająca). Układ taki symulował przestrzeń pierścieniową otworu wiertniczego.

Prace badawcze rozpoczęto od wytworzenie na rdzeniach piaskowca (fotografia 2) osadu z płuczki wiertniczej. Tworzenie osadu polegało na przetłoczeniu

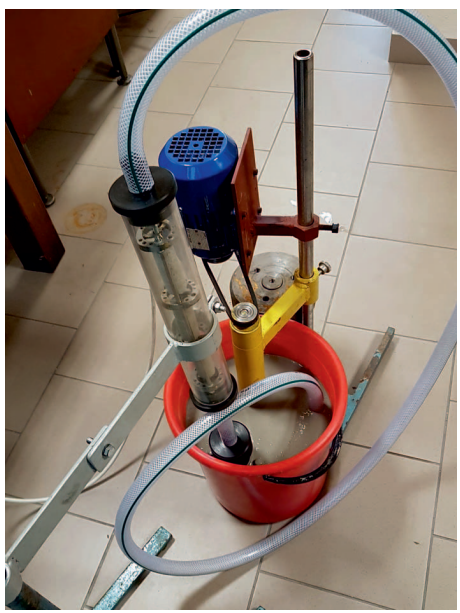

Fot. 1. Otworowy symulator przepływu cieczy wiertniczych (urządzenie w trakcie tłoczenia cieczy) płuczki w symulowanej przestrzeni pierścieniowej i obmywaniu tą płuczką w czasie 1 godziny trzech rdzeni umieszczonych w urządzeniu (fotografia 4). Wydatek tłoczenia płuczki 
został określony na podstawie wstępnych prób i obserwacji prowadzonych podczas testów przygotowujących próbki rdzeni do badań.

Do wytworzenia osadu płuczkowego użyto otworowej płuczki polimerowo-potasowej zawierającej zanieczyszczenia pochodzące z przewiercanych warstw. Wybrano płuczkę z otworu P-2K, ponieważ jej parametry pozwalały na uzyskanie trudno usuwalnego osadu. Następnie po wytworzeniu osadu płuczkowego, rdze-

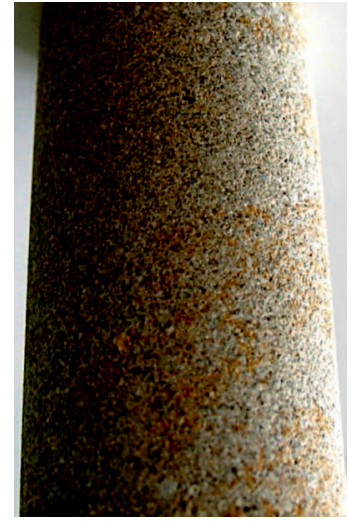

Fot. 2. Rdzeń wycięty z próbki piaskowca nie przemywano przez 4 minuty przy wydatku tłoczenia cieczy przemywającej równym 11,2 1/min. Wytypowanymi cieczami przemywającymi były: woda (jako ciecz wzorcowa), dotychczas stosowana ciecz przemywająca ( $1 \%$ roztwór MDC) oraz hybrydowa ciecz przemywająca. Skład hybrydowej cieczy przemywającej zawierał:

- $0,2 \%$ alkoholu etoksylowanego - niejonowy środek powierzchniowo czynny,

- $0,05 \%$ polimeru przeciwdziałającego frakcjonowaniu,

- $0,1 \%$ drobnoziarnistej lekkiej frakcji ściernej (fotografia 5),

- $0,2 \%$ gruboziarnistej frakcji ściernej o średnim ciężarze (fotografia 6),

- $0,2 \%$ drobnoziarnistej frakcji ściernej poprawiającej parametry hydrauliczne cieczy (fotografia 7),

- $0,01 \%$ środka przeciwdziałającego spienieniu cieczy.

Wprowadzenie stałych frakcji miało na celu uzyskanie dodatkowego efektu mechanicznego usuwania osadu płuczkowego.

Na fotografiach 8-10 przedstawiono wizualny efekt usuwania osa-

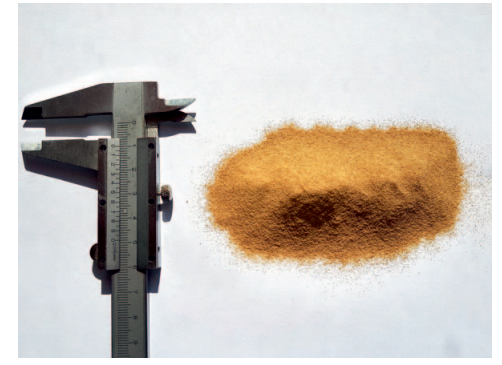

Fot. 5. Lekka frakcja ścierna (środek OM)

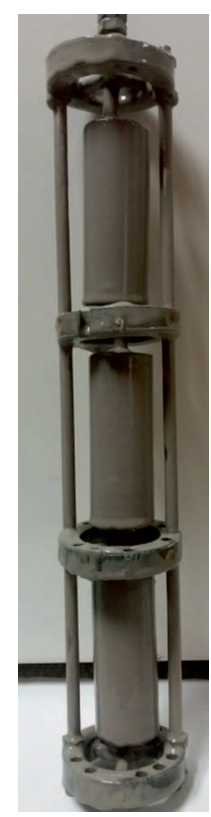

Fot. 4. Rdzenie $\mathrm{z}$ osadem płuczkowym (po przemyciu płuczką)

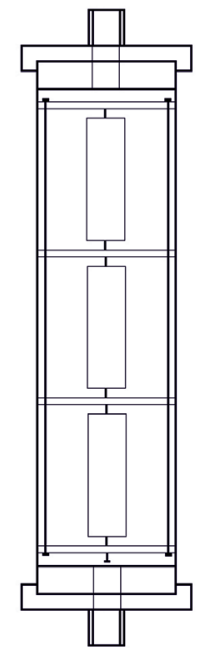

Rys. 2. Schemat rdzeni piaskowca umieszczonych w statywie wewnątrz rury $\mathrm{z}$ tworzywa

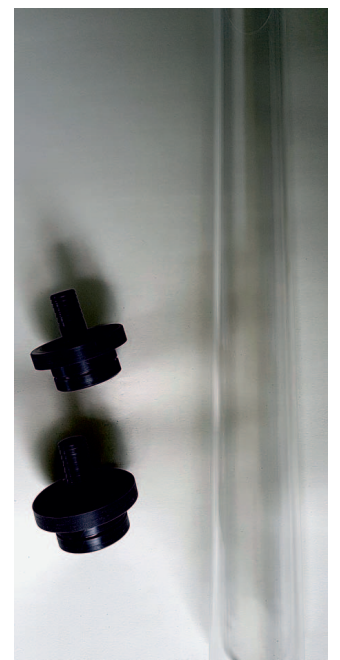

Fot. 3. Widok rury z tworzywa wraz uszczelnieniami, w których umocowano dopływ i odpływ cieczy wiertniczej

du płuczkowego z formacji skalnej w zależności od rodzaju zastosowanej cieczy przemywającej.

Metodyka przyjęta na potrzeby badań umożliwiała wyznaczenie skuteczności usuwania osadu płuczkowego przez tłoczoną ciecz przemywającą, poprzez określenie przyczepności na kontakcie stwardniały zaczyn cementowy-formacja skalna. $\mathrm{W}$ tym celu, próbki rdzeni piaskowca $\mathrm{z}$ utworzonym osadem płuczkowym, po przemyciu daną cieczą przemywającą, zostały umieszczone w formie (fotografia 11) i zalane zaczynem cementowym (fotografia 12), a po wyznaczonym czasie hydratacji, który wynosił 48 godzin, wykonano badanie przyczepności na kontakcie stwardniały zaczyn cementowy-rdzeń skalny. Aby określić przyczepność, próbki umieszczano między dwiema płytami maszyny wytrzymałościowej (fotografia 13) i mierzono siłę zerwania przyczepności na kontakcie stwardniały zaczyn cementowy-skała pod wpływem obciążenia przykładanego na próbkę.

Po każdym pomiarze siły potrzebnej do zerwania przyczepności pomiędzy stwardniałym zaczynem cementowym a skałą obliczono przyczepność wyrażoną w MPa, według wzoru (1):

$$
\sigma_{p}=\frac{P}{S} \cdot 10^{-3}[\mathrm{MPa}]
$$

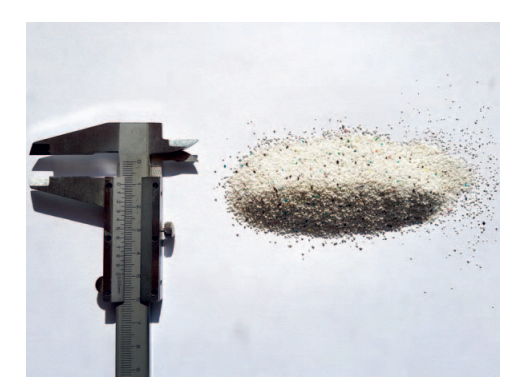

Fot. 6. Frakcja ścierna o średnim ciężarze (środek PŚ)

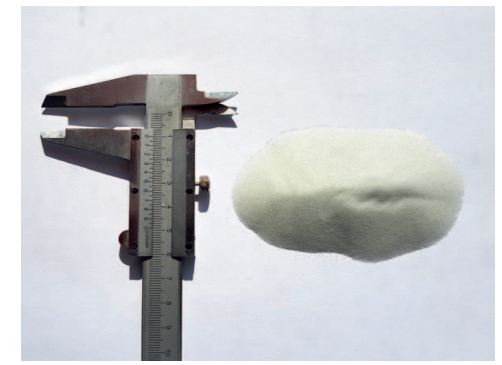

Fot. 7. Frakcja ścierna poprawiająca parametry hydrauliczne cieczy (środek MS) 
gdzie:

$\sigma_{p}-$ przyczepność na kontakcie stwardniały zaczyn cementowy - rdzeń skalny [MPa],

$P$ - siła nacisku powodująca zerwanie połączenia stwardniałego zaczynu cementowego ze skałą [kN],

$s$ - powierzchnia styku próbki skały $\mathrm{z}$ zaczynem cementowym $\left[\mathrm{m}^{2}\right]$.

Bezpośrednio ze wskaźnika maszyny wytrzymałościowej odczytywano siłę nacisku $(P)$, natomiast powierzchnia styku skały ze stwardniałym zaczynem cementowym wynikała z pola powierzchni zewnętrznej użytego do badań rdzenia i wysokości zaczynu cementowego w formie. Na rysunku 3 zestawiono wymiary niezbędne do obliczenia powierzchni styku skały ze stwardniałym zaczynem cementowym.

Są to:

średnica rdzenia $(d)=25 \mathrm{~mm}=0,025 \mathrm{~m}$,

wysokość zacementowanej części rdzenia $(h)=44 \mathrm{~mm}=0,044 \mathrm{~m}$.

$$
\begin{gathered}
s=\pi \cdot d \cdot h \\
s=\pi \cdot 0,025 \cdot 0,044=0,003456\left[\mathrm{~m}^{2}\right]
\end{gathered}
$$

Z czego przyczepność na kontakcie stwardniały zaczyn cementowy - skała $\sigma_{p}$ wyznaczono za pomocą wzoru (4):

$$
\sigma_{p}=\frac{P}{0,003456} \cdot 10^{-3}=\frac{P}{3,456}[\mathrm{MPa}]
$$

W celu określenia przyczepności bazowej (maksymalnej i minimalnej) przeprowadzono dodatkowe badania przyczepności dla „czystego” rdzenia bez osadu płuczkowego oraz dla rdzenia z osadem pluczkowym, lecz z pominięciem etapu usuwania osadu. Do tych wartości (określanych mianem maksy-

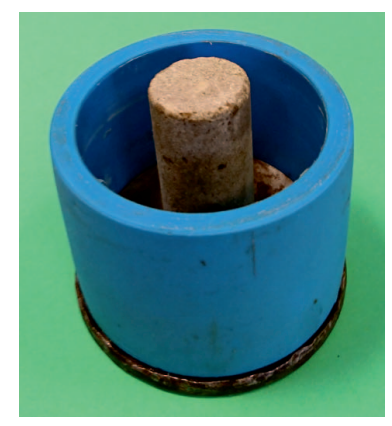

Fot. 11. Próbka rdzenia przygotowana do wypełnienia zaczynem cementowym

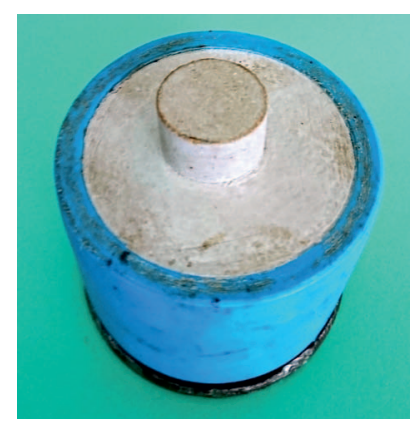

Fot. 12. Próbka przygotowana do badań przyczepności na kontakcie stwardniały zaczyn cementowy - skała

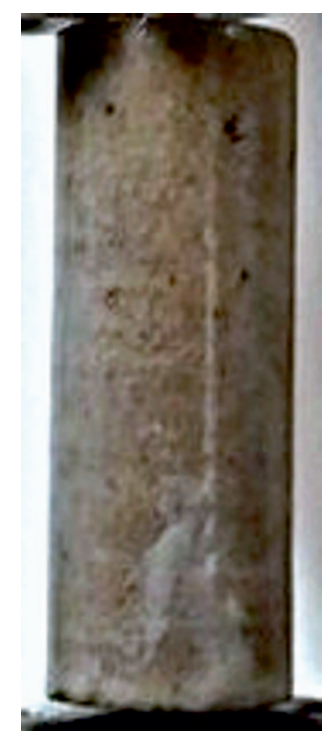

Fot. 9. Ciecz przemywająca: $1 \% \mathrm{r}-\mathrm{r} \mathrm{MDC}$

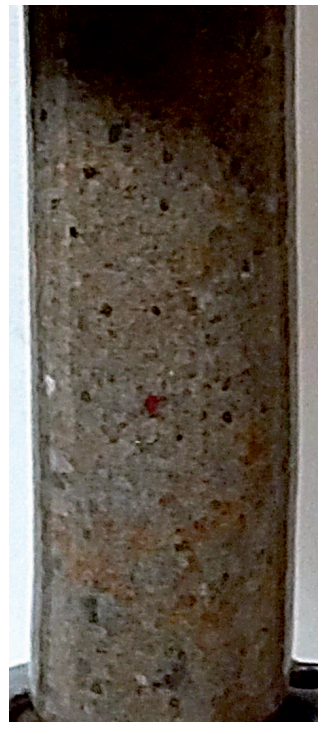

Fot. 10. Hybrydowa ciecz przemywająca zas kontaktu 4 minuty, wydatek tłoczenia 11,2 1/min

malnej i minimalnej przyczepności bazowej) porównywane były kolejne wyniki badań. Wszystkie rdzenie zalewano zaczynem cementowym o tym samym składzie i parametrach, które zamieszczono w tablicy 2. Był to skład zaczynu stosowany do uszczelniania kolumn rur okładzinowych w warunkach temperatury około $25^{\circ} \mathrm{C}$.

Podczas badania przyczepności na kontakcie stwardniały zaczyn cementowy-rdzeń skalny oczyszczony z wytworzonego wcześniej osadu płuczkowego, uzyskano wartości w zakresie od 1,01 $\div 1,24 \mathrm{MPa}$, natomiast hybrydowa ciecz przemywająca pozwalała na usunięcie osadu, skutkujące uzyska-

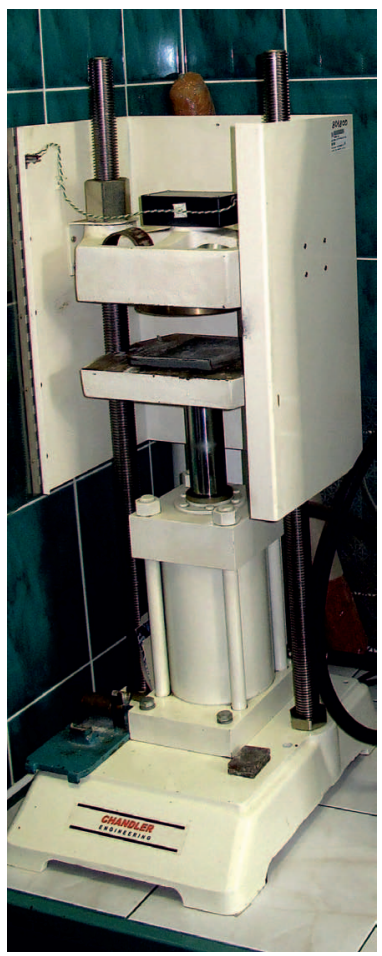

Fot. 13. Maszyna wytrzymałościowa 


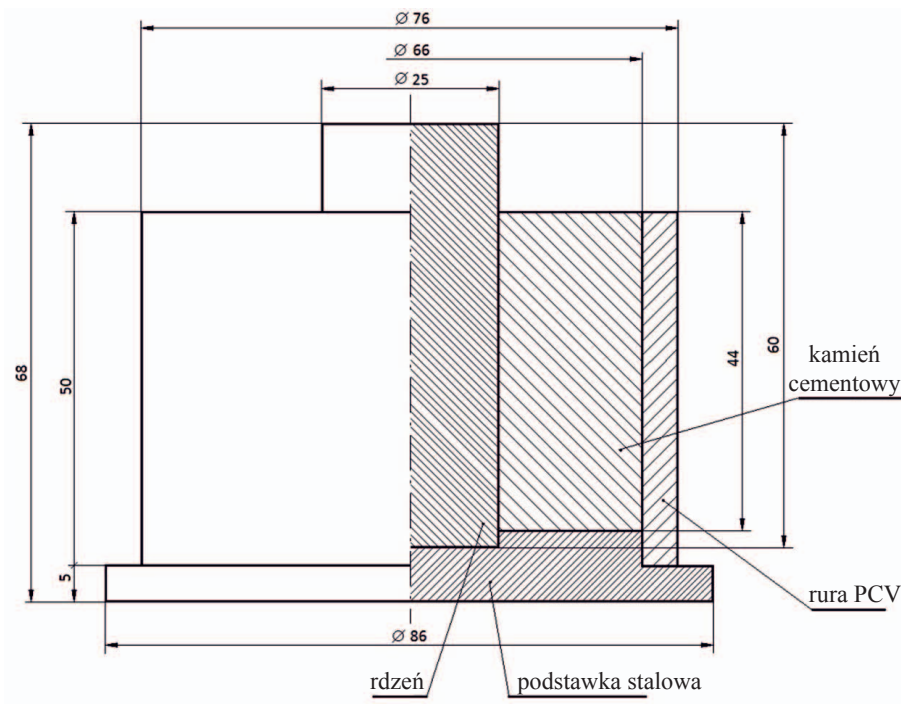

Rys. 3. Półprzekrój formy z umieszczonym rdzeniem próbki

niem przyczepności o wartości 2,26 MPa. Porównując uzyskane wyniki do minimalnej przyczepności bazowej wynoszącej 0,61 MPa, otrzymano wzrost wartości przyczepności w zakresie od 66\% (przy zastosowaniu wody jako cieczy przemywającej) do 103\% (przy użyciu dotychczas stosowanej cieczy przemywającej). Natomiast nowo opracowana hybrydowa ciecz przemywająca pozwoliła na uzyskanie procentowego wzrostu przyczepności w stosunku do minimalnej przyczepności bazowej na poziomie 271\%. Korelując wartości przyczepności z maksymalną przyczepnością ba- zową wynoszącą 2,37 MPa (tablice 1 i 3), otrzymane wyniki były niższe od 57\% przy przemywaniu wodą do niespełna $5 \%$ podczas zastosowania hybrydowej cieczy przemywającej. Uzyskane wartości wraz z porównaniem do maksymalnej i minimalnej przyczepności bazowej przedstawiono w tablicy 3, natomiast graficzne zestawienie wyników skuteczności usuwania osadu filtracyjnego w zależności od zastosowanej cieczy przemywającej i porównanie w stosunku do maksymalnej oraz minimalnej wartości bazowej przedstawiono na rysunku 4.

Analizując uzyskane wyniki badań, zaobserwowano znaczny wzrost przyczepności na kontakcie stwardniały zaczyn cementowy-formacja skalna, a tym samym poprawę usunięcia osadu płuczkowego z formacji skalnej, przy zastosowaniu hybrydowej cieczy przemywającej. Podczas realizacji badań za-

Tablica 1. Bazowa przyczepność na kontakcie stwardniały zaczyn cementowy-skała

\begin{tabular}{|l|c|c|}
\cline { 2 - 3 } \multicolumn{1}{c|}{} & $\begin{array}{c}\text { Siła zerwania } \\
\text { przyczepności }\end{array}$ & $\begin{array}{c}\text { Przyczepność na kon- } \\
\text { takcie stwardniały za- } \\
\text { czyn cementowy-skała }\end{array}$ \\
\cline { 2 - 3 } \multicolumn{1}{c|}{$[\mathrm{kN}]$} & {$[\mathrm{MPa}]$} \\
\hline $\begin{array}{l}\text { Maksymalna } \\
\text { przyczepność bazowa }\end{array}$ & 8,2 & 2,37 \\
\hline $\begin{array}{l}\text { Minimalna } \\
\text { przyczepność bazowa }\end{array}$ & 2,1 & 0,61 \\
\hline
\end{tabular}

Tablica 2. Receptura i parametry zaczynu cementowego stosowanego w badaniu przyczepności na kontakcie stwardniały zaczyn cementowy-skała

\begin{tabular}{|c|c|c|c|c|c|c|c|c|c|c|c|}
\hline \multirow{2}{*}{\multicolumn{3}{|c|}{ Skład zaczynu }} & \multicolumn{9}{|c|}{ Parametry zaczynu } \\
\hline & & & \multicolumn{7}{|c|}{ Gęstość $\left[\mathrm{g} / \mathrm{cm}^{3}\right]$} & & 1,78 \\
\hline \multicolumn{2}{|l|}{ Woda } & $\mathrm{w} / \mathrm{c}=0,45$ & \multicolumn{7}{|c|}{ Rozlewność [mm] } & & 240 \\
\hline \multicolumn{2}{|l|}{ Środek odpieniający } & $0,5 \%$ & \multicolumn{7}{|c|}{ Odstój wody [\%] } & & 0,0 \\
\hline \multicolumn{2}{|c|}{ Środek upłynniający } & $0,2 \%$ & \multicolumn{7}{|c|}{ Lepkość plastyczna $[\mathrm{mPa} \cdot \mathrm{s}]$} & & 91,5 \\
\hline \multicolumn{2}{|c|}{ Środek antyfiltracyjny } & $0,2 \%$ & \multicolumn{7}{|c|}{ Granica płynięcia $[\mathrm{Pa}]$} & & 6,48 \\
\hline \multicolumn{2}{|l|}{ Chlorek wapnia } & $4,0 \%$ & \multicolumn{7}{|c|}{ Wytrzymałość strukturalna [Pa] } & & 2,88 \\
\hline \multicolumn{2}{|c|}{ Chlorek potasu (bwow $\left.{ }^{1}\right)$} & $3,0 \%$ & \multicolumn{7}{|c|}{ Filtracja $\left[\mathrm{cm}^{3} / 30 \mathrm{~min}\right]$} & & 36,0 \\
\hline \multicolumn{2}{|l|}{ Lateks } & $10,0 \%$ & \multirow{2}{*}{\multicolumn{4}{|c|}{ Czas gęstnienia w temperaturze $25^{\circ} \mathrm{C}$}} & \multicolumn{3}{|c|}{ wartość $30 \mathrm{Bc}^{2}$ [h:min] } & & $2: 55$ \\
\hline \multicolumn{2}{|l|}{ Stabilizator lateksu } & $1,0 \%$ & & & & & \multicolumn{3}{|c|}{ wartość $100 \mathrm{Bc}$ [h:min] } & & $3: 32$ \\
\hline \multicolumn{2}{|l|}{ Mikrocement } & $10,0 \%$ & \multirow{2}{*}{\multicolumn{4}{|c|}{ Czas wiązania w temperaturze $20^{\circ} \mathrm{C}$}} & \multicolumn{3}{|c|}{ początek [h:min] } & & $4: 45$ \\
\hline \multicolumn{2}{|c|}{ Cement CEM I 32,5R } & $100 \%$ & & & & & \multicolumn{3}{|c|}{ koniec [h:min] } & & $5: 35$ \\
\hline \multicolumn{2}{|c|}{ Środek spęczniający } & $0,3 \%$ & \multicolumn{5}{|c|}{ Wytrzymałość na ściskanie po 48 godz. [MPa] } & \multicolumn{4}{|c|}{10,6} \\
\hline \multirow{2}{*}{$\begin{array}{l}\text { Parametry } \\
\text { reologiczne temp: } \\
{\left[20^{\circ} \mathrm{C}\right]}\end{array}$} & $\mathrm{obr} / \mathrm{min}$ & 600 & 300 & 200 & 100 & 60 & 30 & 6 & 3 & $10 \mathrm{~s}$ & $10 \mathrm{~min}$ \\
\hline & $\begin{array}{l}\text { odczyt w } \\
\text { [j.f] }\end{array}$ & 187 & 105 & 74 & 44 & 27 & 17 & 6 & 4 & 6 & 16 \\
\hline
\end{tabular}

Ilości wszystkich środków oprócz chlorku potasu podano procentowo w stosunku do ilości cementu.

\footnotetext{
${ }^{1}$ Bwow (ang. by weight of water) - w stosunku do ilości wody zarobowej.

${ }^{2} \mathrm{Bc}$ - jednostka konsystencji gęstnienia zaczynu cementowego podczas pomiaru w konsystometrze.
} 
Tablica 3. Wartości przyczepności na kontakcie stwardniały zaczyn cementowy-skała dla wybranych cieczy przemywających; czas kontaktu cieczy 4 minuty; wydatek przepływu 11,2 1/min

\begin{tabular}{|l|c|c|c|c|}
\hline \multirow{2}{*}{$\begin{array}{c}\text { Rodzaj środka do } \\
\text { sporządzenia cieczy } \\
\text { przemywającej }\end{array}$} & $\begin{array}{c}\text { Siła zerwania } \\
\text { przyczepności }\end{array}$ & $\begin{array}{c}\text { Przyczepność na kontakcie } \\
\text { stwardniały zaczyn cemen- } \\
\text { towy-skała }\end{array}$ & $\begin{array}{c}\text { Procentowe obniże- } \\
\text { nie przyczepności w sto- } \\
\text { sunku do maksymalnej } \\
\text { przyczepności bazowej }\end{array}$ & $\begin{array}{c}\text { Procentowy wzrost przy- } \\
\text { czepności w stosunku do } \\
\text { minimalnej przyczepności } \\
\text { bazowej }\end{array}$ \\
\cline { 2 - 5 } $\begin{array}{l}\text { Maksymalna } \\
\text { przyczepność bazowa }\end{array}$ & 8,2 & 2,37 & - & - \\
\hline $\begin{array}{l}\text { Minimalna } \\
\text { przyczepność bazowa }\end{array}$ & 2,1 & 0,61 & $\downarrow$ & - \\
\hline Woda & 3,5 & 1,01 & $\downarrow 57 \%$ & $\uparrow 66 \%$ \\
\hline $\begin{array}{l}\text { Dotychczas stosowany } \\
\text { środek MDC }\end{array}$ & 4,3 & 1,24 & $\mathbf{k 8 \%}$ & $\uparrow \mathbf{1 0 3 \%}$ \\
\hline Ciecz hybrydowa & $\mathbf{7 , 8}$ & $\mathbf{2 , 2 6}$ & $\downarrow \mathbf{5 \%}$ & $\uparrow \mathbf{2 7 1 \%}$ \\
\hline
\end{tabular}

* Niepewność mierzonych wielkości fizycznych zawartych w tablicy 3 oszacowano według klasy dokładności urządzenia pomiarowego na poziomie $0,1 \%$ (siła zerwania przyczepności).

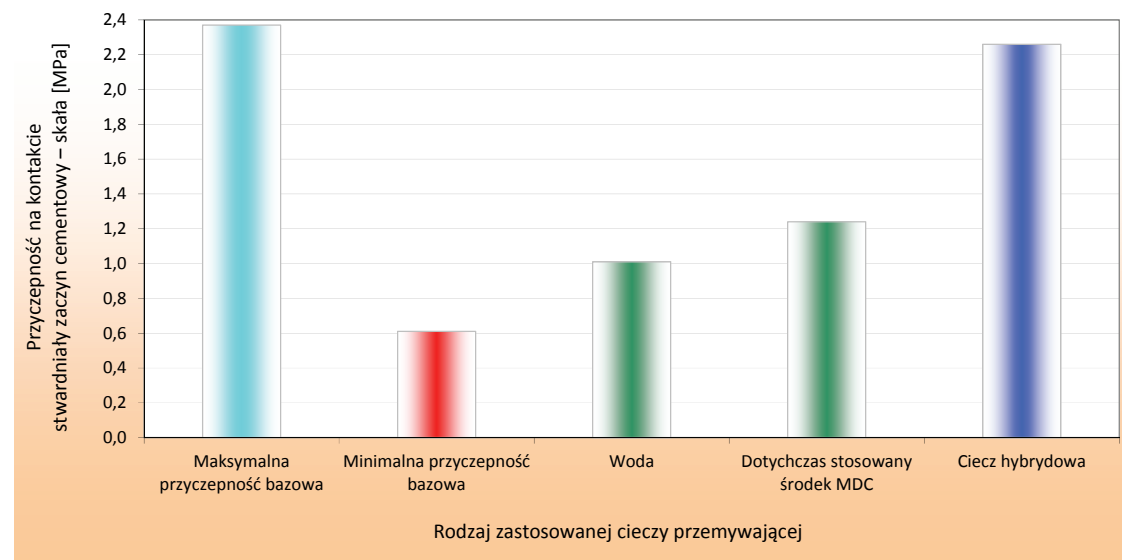

Rys. 4. Przyczepność na kontakcie stwardniały zaczyn cementowy-skała dla różnych cieczy przemywających przy wydatku tłoczenia 11,2 1/min; czas kontaktu cieczy przemywającej 4 minuty

wartością niemal porównywalną do wartości przyczepności bazowej wynoszącej 2,37 MPa. Również obniżenie wartości w stosunku do maksymalnej wartości bazowej wynosiło tylko 5\%. Ciecz tego rodzaju uznano za najlepiej usuwającą osad wytworzony z płuczki polimerowo-potasowej.

Na podstawie zrealizowanych prac badawczych stwierdzono korzystny wpływ dodatku frakcji ściernych do cieczy przemywającej na efektywność usuwania osadu płuczkowego. Działanie takie obserwowano podczas badań usuwania osadu powstałego z płuczki polimerowo-potasowej. Należy pamiętać, że nie można uogólniać efektywności działania da-

projektowano hybrydową ciecz przemywającą, która wykazywała dwufunkcyjną właściwość oczyszczającą (chemiczno-mechaniczną). W celu wyeliminowania tworzenia się piany zastosowano 0,01\% środka odpieniającego. Zastosowanie hybrydowej cieczy przemywającej skutkowało (w warunkach laboratoryjnych) prawie trzykrotnym wzrostem wartości przyczepności w stosunku do minimalnej przyczepności bazowej, co było nej cieczy i uwzględniać zróżnicowanie tworzącego się osadu płuczkowego. Odmienny charakter osadu zależny jest od rodzaju przewiercanej formacji skalnej, rodzaju i parametrów płuczki wiertniczej oraz warunków otworowych (temperatura i ciśnienie). W związku z czym należy indywidualnie dobierać ciecz przemywającą do danego otworu oraz występujących warunków geologiczno-technicznych.

\section{Wnioski}

W trakcie badań nad opracowaniem hybrydowej cieczy przemywającej oraz analizy efektywności działania tej cieczy wyciągnięto następujące wnioski:

- najlepszą efektywność usuwania osadu wytworzonego z płuczki polimerowo-potasowej umożliwia stosowanie cieczy przemywających zawierających mieszaninę odpowiednio dobranej koncentracji środków,

- dodatek do cieczy przemywającej (drobno- i gruboziarnistych) frakcji ściernych, skutkował poprawą efektywności usuwania osadu poprzez dodatkowe mechaniczne zdzieranie powstałego osadu płuczkowego,

- opracowana hybrydowa ciecz przemywająca wykazywała bardzo dobre właściwości oczyszczające zarówno poprzez chemiczne, jak i mechaniczne oddziaływanie na wytworzony na powierzchni skały osad płuczkowy,

- zastosowanie hybrydowej cieczy przemywającej skutkowało prawie trzykrotnym wzrostem wartości przyczepności na kontakcie stwardniałego zaczynu cementowego 
z formacją skalną, co było wartością niemal porównywalną do przyczepności bazowej,

- uzyskano (po zastosowaniu hybrydowej cieczy przemywającej) obniżenie wartości przyczepności w stosunku do maksymalnej wartości bazowej na poziomie niespełna 5\% (przyczepność na kontakcie stwardniały zaczyn cementowy-formacja skalna),
- hybrydową ciecz przemywającą uznano za najlepiej usuwającą osad wytworzony z płuczki polimerowo-potasowej.

Należy mieć na uwadze, że badania skuteczności usuwania osadu płuczkowego prowadzone w warunkach laboratoryjnych nie odzwierciedlają stanu faktycznego w otworze, jednak skonstruowany symulator przepływu cieczy wiertniczych pozwala symulować warunki semiotworowe.

Prosimy cytować jako: Nafta-Gaz 2018, nr 5, s. 372-379, DOI: 10.18668/NG.2018.05.04

Artykuł nadesłano do Redakcji 23.01.2018 r. Zatwierdzono do druku 20.03.2018 r.

Artykuł powstał na podstawie pracy badawczej pt.: Analiza możliwości poprawy oczyszczenia przestrzeni pierścieniowej otworu wiertniczego przed zabiegiem cementowania - praca INiG - PIB na zlecenie MNiSW, nr zlecenia: 58/KW/17, nr archiwalny: DK-4100/58/17.

\section{Literatura}

[1] Błaż S.: Nowe rodzaje cieczy przemywajacych osady z płuczki inwersyjnej przed zabiegiem cementowania otworów wiertniczych. Nafta-Gaz 2017, nr 5, s. 302-311, DOI: 10.18668/ NG.2017.05.02.

[2] Habrat S., Raczkowski J., Zawada S.: Technika i technologia cementowań w wiertnictwie. Wydawnictwo Geologiczne, Warszawa 1980.

[3] Herman Z: Doskonalenie procesu cementowania rur okładzinowych $w$ otworach wierconych przy użyciu płuczek: polimerowej $z$ inhibitorem i polimerowej $z$ inhibitorem kapsutujacym $w$ wybranych rejonach Karpat i przedgórza Karpat. Etap 01 - Opracowanie receptur zaczynów cementowych i technologii cementowania kolumn rur okładzinowych $w$ wytypowanych rejonach wierceń w Karpatach Wschodnich. Praca niepublikowana INiG, Kraków 1995.

[4] Herman Z.: Doskonalenie procesu cementowania rur okładzinowych w otworach wierconych przy użyciu pluczek: polimerowej $z$ inhibitorem i polimerowej z inhibitorem kapsułujacym $w$ wybranych rejonach przedgórza Karpat. Etap 02 - Opracowanie receptur zaczynów cementowych i technologii cementowania dla wybranych rejonów skał zbiornikowych przedgórza Karpat. Praca niepublikowana INiG, Kraków 1995.

[5] Jasiński B.: Ocena wpływu cieczy przemywajacej na jakość zacementowania rur $w$ otworze wiertniczym po użyciu pluczki glikolowo-potasowej. Nafta-Gaz 2016, nr 6, s. 413-421, DOI: 10.18668/NG.2016.06.04.

[6] Kremieniewski M.: Ograniczenie ekshalacji gazu w otworach wiertniczych poprzez modyfikację receptur oraz ksztattowanie się struktury stwardniałych zaczynów uszczelniajacych. Prace INiG - PIB, Kraków 2016.

[7] Kremieniewski M., Rzepka M.: Przyczyny i skutki przeptywu gazu

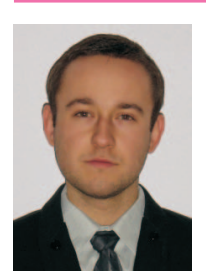

Dr inż. Marcin KREMIENIEWSKI

Adiunkt w Zakładzie Technologii Wiercenia.

Instytut Nafty i Gazu - Państwowy Instytut Badawczy

ul. Lubicz 25 A

31-503 Kraków

E-mail: marcin.kremieniewski@inig.pl w zacementowanej przestrzeni pierścieniowej otworu wiertniczego oraz metody zapobiegania temu zjawisku. Nafta-Gaz 2016, nr 9, s. 722-728, DOI: 10.18668/NG.2016.09.06.

[8] Nelson E.B. et al.: Well Cementing. Schlumberger Educational Service, Houston, Teksas 1990.

[9] Stryczek S., Gonet A.: Kierunki ograniczania migracji gazu z przestrzeni pierścieniowej otworu wiertniczego. WUG: bezpieczeństwo pracy i ochrona środowiska w górnictwie, 2005 nr 3, s. 10-13.

[10] Studia nad doborem zaczynów uszczelniajacych $w$ warunkach wierceń w basenie pomorskim. Praca zbiorowa pod red. S. Stryczka. Prace AGH, Kraków 2016.

[11] Uliasz M.: Kompleksowa analiza przyczyn migracji gazu $w$ otworach realizowanych na przedgórzu Karpat i w Karpatach pod katem właściwości cieczy wiertniczych stosowanych w czasie wiercenia i cementowania kolumn rur okładzinowych. Praca nieopublikowana, INiG, Kraków 2012, nr zlecenia: 529/ KW/11, nr archiwalny: DK-4100-86/11.

[12] Uliasz M., Chudoba J., Herman Z.: Pluczki wiertnicze z inhibitorami polimerowymi i ich oddziatywanie na przewiercane skaty. Prace INiG nr 139, 2006.

[13] Uliasz M., Zima G., Błaż S., Jasiński B.: Systemy ptuczek wiertniczych do wiercenia otworów $w$ formacjach tupkowych. Prace Naukowe INiG 2012 „Rzeczpospolita łupkowa” nr 183, s. 225-241.

[14] Uliasz M.. Zima G., Błaż S., Jasiński B.: Ocena wpływu cieczy wiertniczych $w$ aspekcie zapobiegania migracji gazu $w$ otworach na przedgórzu Karpat. Nafta-Gaz 2015, nr 1, s. 11-17.

[15] Zima G.: Wpływ właściwości płuczek wiertniczych na jakość cementowania w gazonośnych poziomach miocenu. Nafta-Gaz 2014, nr 12, s. 899-907.

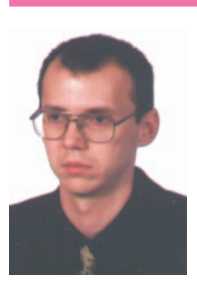

Dr inż. Marcin RZEPKA

Kierownik Laboratorium Zaczynów Uszczelniających w Zakładzie Technologii Wiercenia.

Instytut Nafty i Gazu - Państwowy Instytut Badawczy

ul. Lubicz $25 \mathrm{~A}$

31-503 Kraków

E-mail: marcin.rzepka@inig.pl 